\title{
Trace fossils from the Upper Pleistocene glaciolacustrine laminated sediments of Lithuania
}

\author{
Alfred Uchman, \\ Algirdas Gaigalas,
}

Vaidotas Kazakauskas
Uchman A., Gaigalas A., Kazakauskas V. Trace fossils from the Upper Pleistocene glaciolacustrine laminated sediments of Lithuania. Geologija. Vilnius. 2008. Vol. 50. No. 3(63). P. 212-226. ISSN 1392-110X

Detailed studies of trace fossils have been carried out in five sections of glaciolacustrine varved sediments (Balbieriškis 2 and 3 outcrops, clay pits of Pašaminè, Krūna and Tauragè). Trace fossils Gordia isp., Helminthoidichnites isp. and Galaciichnium liebegastensis are relatively common, and Cochlichnus anguineus, Warvichnium ulbrichi and curved ridges are rare. These trace fossils are typical of the Mermia ichnofacies. Their occurrence is related to the warmer climate of the Late Pleistocene North European glacial interphasials or interoscillations. The trace fossils can be used for recognition of lacustrine subfacies and climatic warming.

Key words: trace fossils, Pleistocene, varved clay, glaciolacustrine sediments, proglacial lakes, Lithuania

Received 06 May 2008, accepted 27 June 2008

Alfred Uchman. Institute of Geological Sciences, Jagiellonian University, ul. Oleandry 2a, Pl-30063 Kraków, Poland. E-mail: alfred.uchman@uj.edu.pl; Algirdas Gaigalas. Department of Geology and Mineralogy, Vilnius University, M. K. Čiurlionio 21/27, LT-03101 Vilnius, Lithuania. E-mail: Algirdas.Gaigalas@gf.vu.lt; Vaidotas Kazakauskas. Institute of Geology and Geography, T. Ševčenkos str. 13, LT-03223 Vilnius, Lithuania. E-mail: kazakauskas@geo.lt

\section{INTRODUCTION}

For a very long time, in Lithuania proglacial lakes have been considered as having extreme environmental conditions in very cold arctic climate. However, ichnological investigations of glaciolacustrine sediments in the Balbieriškis and Girininkai sections, carried out in 2003, suggest that the bottom of proglacial lakes was not an arctic desert, but a habitat for different invertebrates.

Recently, trace fossils have become a powerful tool in analysing continental palaeoenvironments, including lacustrine settings (e. g., Buatois, Mángano, 1998, 2007). Pleistocene proglacial lake sediments are less common objects of ichnological research; however, their sediments, mostly varved clays, are common in the Northern Hemisphere. The environment of such lakes is extreme for life. Commonly, the lakes are considered as an "arctic desert" whose sediments do not contain fossils and biogenic structures. However, scattered literature on trace fossils from Pleistocene varved clays is known since the end of the 19th century. They were found in Sweden (Högbom, 1893, 1915; Andersson, 1897), Finland (Andersson, 1897; Gibbard, 1977), USA (Emerson, 1898; Tarr, 1935; Ashley, 1975; Ridge, Larsen, 1990; Johnson et al., 1999; Benner, Ridge, 2006, 2007; Benner et al., 2006, 2008), Poland (Schwarzbach, 1938, 1940; Ludwig, 1963; Merta, 1980; Skompski, 1991), Germany (Dahm, Otto, 1953; Murawski, 1964; Hannemann, 1965; Walter, 1985, 1986; Fuchs, 1988; Walter, Suhr, 1998), Austria (Fliri et al., 1971),
Canada (Banerjee, 1973; Gibbard, Dreimanis, 1978), England (Gibbard, Stuart, 1974), and Lithuania (Gaigalas, Uchman, 2004; Uchman et al., 2007). The literature review shows that most of the researches have been focussed on the occurrence of ichnotaxa and their interpretation (e. g., Gibbard, Dreimanis, 1978; Walter, 1985; Skompski, 1991) or rarely on their vertical distribution and relation to facies (Walter, Suhr, 1998; Gaigalas, Uchman, 2004; Uchman et al., 2007). Our present study concerns the distribution of trace fossils in five sections of glaciolacustrine clays (Pašaminè-1, Balbieriškis 2 and 3, Krūna-1 and Tauragè-1). In this paper, we would like to present and interpret trace fossils, some aspects of their vertical distribution and their comparison among different glaciolacustrine basins.

\section{PREVIOUS RESEARCH OF GLACIOLACUSTRINE SEDIMENTS IN LITHUANIA}

The former research of glaciolacustrine basins was concentrated on a study of their geomorphology and palaeogeography (Galvydyte, 1958; Basalykas, 1960, 1962, 1965, 1967, 1981; Gudelis, Mikaila, 1960; Garunkštis, 1961; Mikalauskas, Mikutienė, 1970; Klimavičienè, 1973), emphasizing the distribution and formation of the glaciolacustrine laminated sediments (Mikaila, 1957, 1962a; Gudelis, Mikaila, 1960; Kazakauskas, Gaigalas, 2000; Kazakauskas, 2001), including their value as the most important natural resource (Mikaila, 1962b). Moreover, the basic researches on the structure, texture and lithological composition of the glaciolacus- 
trine sediments (Mikaila, 1966) and relationships between their sedimentation in the largest glaciolacustrine basins and the last glacial ice cover (Mikaila, 1958) have been carried out. During the latest years, sedimentological research of the post-glacial glaciolacustrine sediments was carried out and relationships between the palaeogeographic situation and glaciolacustrine sedimentation were established (Kazakauskas, Gaigalas, 2000, 2004). The general deglaciation pattern in Lithuania was presented by Gaigalas (1994). The Lithuanian largest glaciolacustrine basins were ascribed to the facies of proglacial lakes that developed through the interaction of glacial and proglacial environments (Šinkūnas, Jurgaitis, 1998). The damming of proglacial lakes depended on the character of the on the surface topography of the deglaciated territory. Basalykas (1965) identified the shorelines of proglacial lakes at the following altitudes: 120-130, 115-102, 85-80, 60, 40, 20-16, $8-6 \mathrm{~m}$ a. s. 1 . The glaciolacustrine sediments were frequently deposited on the uneven surface of basal till deposits whose surface altitudes range from $37 \mathrm{~m}$ to $132 \mathrm{~m}$ a.s.l. Generally, the thickness of glaciolacustrine sediments varies from 1-2 to $26 \mathrm{~m}$. In the Dysna basin, they are up to 7-9 $\mathrm{m}$ thick in the central part and ca. $15 \mathrm{~m}$ in the deepest parts, in the Vievis-Širvintos basin reaching 3-5 m, in the Simnas-Balbieriškis basin from a few to $20 \mathrm{~m}$, in the KaunasKaišiadorys basin from 1-2 to $26 \mathrm{~m}$, in the Jūra-Šešupe basin from 2 to $15 \mathrm{~m}$, in the Venta basin from a few to $18.5 \mathrm{~m}$; in the Mūša basin the thickness reaches 3-4 $\mathrm{m}$ in the central zone and up to $10 \mathrm{~m}$ in the northern zone. Such a variety in the thickness of glaciolacustrine sediments was generally caused by the basins' floor topography. The roughness of their surface was smoothed away by the filling up of glaciolacustrine basins with sediments.

Proglacial lakes were dammed near the margin of the receding ice-sheet of the last (Nemunas) glaciation. The maximum of the Nemunas Glaciation in Lithuania dates to about 20,000-18,000 years BP (Grūda stadial). The glacier of the Baltija stadial reached its maximum at 17,000-16,000 years ago retreating from its maximum areal range (Fig. 1) re-advanced several times and formed the recessional end moraine ridges of

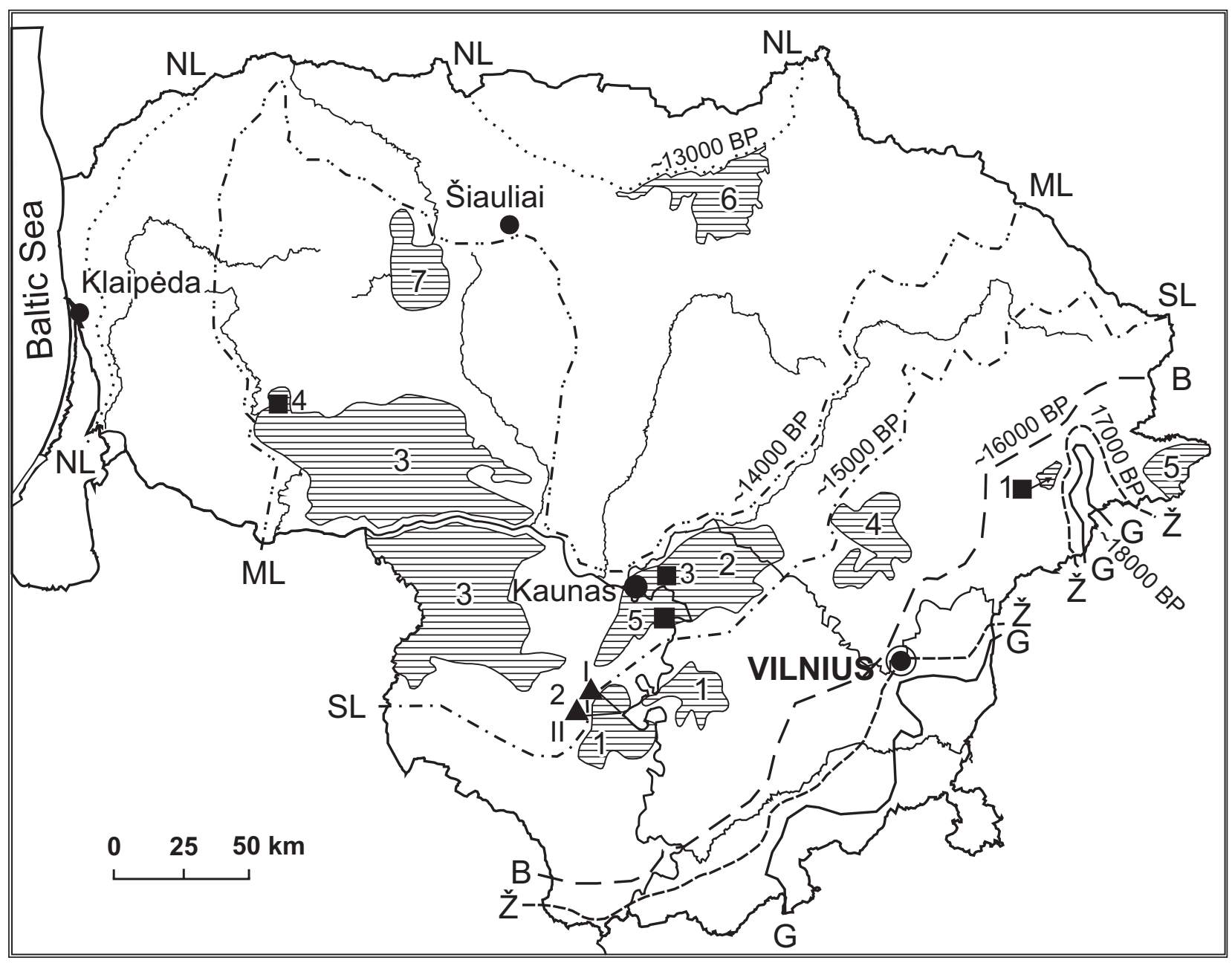

Fig. 1. Location of glaciolacustrine basins and study sections with indication of limits of retreating ice-sheet in Lithuania. Glaciolacustrine basins:

1 - Simnas-Balbieriškis, 2 - Kaunas-Kaišiadorys, 3 - Jūra-Šešupè, 4 - Vievis-Širvintos, 5 - Dysna, 6 - Mūša, 7 - Venta. Limits of stadials and phasials of retreating ice-sheet: $G$ - Grūda Stadial, Ž - Žiogeliai Phasial, B - Baltija Stadial, SL - South Lithuanian Phasial, ML - Middle Lithuanian Phasial, NL - North Lithuanian Phasial. Sites of investigated sections: 1 - Pašaminè-1, 2 - Balbieriškis outcrops. I- section 1, II - sections 2 and 3, 3- Krūna-1, 4 - Tauragè-1, 5-Girininkai-1

1 pav. Limnoglacialinių baseinų ir tirtų pjūvių padètis žemèlapyje su atsitraukiančios ledyno dangos ribomis Lietuvoje. Limnoglacialiniai baseinai:

1 - Simnas-Balbieriškis, 2 - Kaunas-Kaišiadorys, 3 - Jūra-Šešupè, 4 - Vievis-Širvintos, 5 - Dysna, 6 - Mūša, 7 -Venta. Atsitraukiančio ledyno stadijų ir fazių ribos: G - Grūdos stadijos, Ž - Žiogelių fazés, B - Baltijos stadijos, SL - Pietų Lietuvos fazės, ML - Vidurio Lietuvos fazės, NL - Šiaurès Lietuvos fazès. Tyrinètų pjūvių vietos: 1 - Pašaminės-1 pjūvis, 2 - Balbieriškio I atodangos 1 pjūvis, Balbieriškio Il atodangos 2 ir 3 pjūviai, 3 - Krūnos-1 pjūvis, 4 - Tauragès-1 pjūvis, 5 - Girininkų-1 pjūvis 
the South Lithuanian, Middle Lithuanian, and North Lithuanian phases (Gudelis, Mikaila, 1960). Three oscillatory moraine branches are traced in the zone of South Lithuania's recessional phase. All phasial halts of the glacier margin caused the development of proglacial lakes whose size and duration were different. The largest glaciolacustrine basins were dammed near the glacier margin during the South Lithuanian phase (Simnas-Balbieriškis, Vievis-Širvintos), Middle Lithuania (Kaunas-Kaišiadorys, Jūra-Šešupè), and North Lithuanian (Venta, Mūša) recessional phases.

Thus, the distribution of the largest glaciolacustrine basins in the territory of Lithuania (Fig. 1) and the formation of glaciolacustrine clayey sediments were closely related to the character of the retreat of the ice-sheet at the end of Nemunas Glaciation, the topography of the deglaciated territory, and climatic variations. Mostly these factors controlled formation of different sedimentary series which reflect the dynamics of glacier degradation which, in turn, was determined by the recessions and oscillations of phasial glaciers. In varved clay sections of the Balbieriškis outcrop and the Girininkai clay pit, trace fossils (Gordia, Helminthoidichnites, Glaciichnium, Cochlichnus, Warvichnium, and curved ridges) were found for the first time (Gaigalas, Uchman, 2004). The presence of trace fossils in Upper Pleistocene varved clays of proglacial glaciolacustrine basins reflect the climatic fluctuations during glaciolacustrine - lacustrine sedimentation of the South-Lithuanian, Middle-Lithuanian or North-Lithuanian phasials and interphasials of the Baltija stadial of the Nemunas Glaciation. Trace fossils in varved sediments in combination with some sedimentological data suggest the existence of warmer climatic episodes 13-16 thousand years BP.

\section{MATERIALS AND METHODS}

The vertical distribution of trace fossils was examined in five sections located in four different glaciolacustrine basins: Balbieriškis-2 Balbieriškis-3 sections (Simnas-Balbieriškis glaciolacustrine basin), Pašaminè-1 section (local glaciolacustrine basin), Krūna-1 section (Kaunas-Kaišiadorys glaciolacustrine basin) and Tauragè-1 section (Jūra-Šešupè glaciolacustrine ba$\sin )$. The described trace fossils were observed on parting surfaces during a careful splitting of the varved clays lamina by lamina. Occurrences of trace fossils are confined only to some, commonly single, lamina, rarely to adjacent two or three laminae. Most of the trace fossil bearing laminae are about one or two decimetres apart in the sections. The laminae are more clayey and less marly than the laminae without trace fossils. The behavioural record of benthic organisms was observed on the surface of winter sediment layers, because they were active in summer. In some cases, especially in the lower part of the Tauragè- 1 section, it was hard to separate all parting surfaces in the field because some laminae were very thin and too fragile. It was possible in the laboratory, where block samples (size $20 \times 15 \times 6 \mathrm{~cm}$ ) were dried at a temperature of $20^{\circ} \mathrm{C}$ for $2-3$ nights. Some thin clayey laminae split much better after some drying, but some silty laminae were split very badly both wet or dry. Some trace fossils in clay lamina were hidden under a sub-millimetre lamina of silt. They became better visible after a delicate scrapping of the silt by a soft brush or cloth.
As we mention in the introduction, ichnological investigation of glaciolacustrine varved clay in Lithuania started in 2003 (Gaigalas, Uchman, 2004), and later they were carried out gradually, step by step: the Pašaminès-1, Balbieriškis-2, Balbieriškis-3 and Krūna-1 sections in 2004, the Pašaminè-2 section (vertical and horizontal profiles) in 2005, and the Tauragè-1 section in 2007. The trace fossils of the Pašaminè-2 section (Uchman et al., in press) are not analysed in this paper.

\section{DISTRIBUTION OF TRACE FOSSILS IN THE STUDY SECTIONS}

Each section of glaciolacustrine basins displays a characteristic distribution of trace fossils. The composition of trace fossil assemblages and the abundance of ichnotaxa vary from section to section. As is shown in the Pašaminès-2 section (Uchman et al., in press), trace fossils display also lateral changes because of their patchy distribution along the laminae.

The Pašaminè-1 section is located in an active clay pit

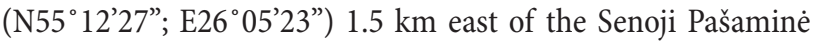
village and $7 \mathrm{~km}$ northeast of the Švenčionèliai town. It displays a $300 \mathrm{~m}$ long, 6-7 $\mathrm{m}$ high inclined exploitation wall oriented south-north (azimuth $170^{\circ}$ ). The clay pit was being exploited in 2004 by the Švenčionèliai ceramic plant. Varved clays of the studied Pašaminè-1 section (Fig. 2) reflect sedimentation in a local glaciolacustrine basin during the East Lithuanian phase of the Baltija stadial of the Nemunas (Weichselian) Glaciation. They occur in a $2 \mathrm{~km}$ wide and $4 \mathrm{~km}$ long area and are surrounded by marginal till deposits. The maximal thickness of the glaciolacustrine sediments in the western part of the area reaches $23 \mathrm{~m}$ and 5-6 $\mathrm{m}$ in the other parts. The glaciolacustrine basin was dammed with the end moraine of the receding inland-ice of the last glaciation. It originated as a result of filling up a local depression with melt waters. It is important to note that the glaciolacustrine basin existed during different phases of recessions and oscillations of the glacial cover. The sediments studied refer to the Daniglacial time of the Late Pleistocene.

According to the lithology and character of lamination, the Pašamine section can be subdivided into three units which reflect different sedimentation conditions. The lower unit, which is located below the bottom of the clay pit, was not investigated. It is composed of silt and fine sand layers and lenses of clay and silt; it reflects the initial stage of the proglacial lake formation.

The middle unit (Fig. 2; 0.7-3.23 m) is composed of varved sediments (mostly silts and clays) intercalated with layers of greyish brown or dark brown clay with laminae of grey silt. The varved sediments contain the ichnofossils studied. The middle unit originated in a stratified proglacial lake without a contact with the glacier as can be supposed from the lack of dropstones.

The upper unit is composed of light yellow silt (3.23-7.50 m), massive clay with local convolute deformations, and two horizons of loaded sand lenses. It reflects the late stage of sedimentation in a non-stratified proglacial lake with encroaching fluvial sedimentation. It is covered by a $40-70 \mathrm{~cm}$ thick layer of fluvial sand and silt. At $7.50 \mathrm{~m}$, the present surface of the pit with removed soil and sand cover is present.

The trace fossils occur in the middle unit $(0.7-3.23 \mathrm{~m})$ of the Pašamine-1 section (Fig. 2). In the first varved package 


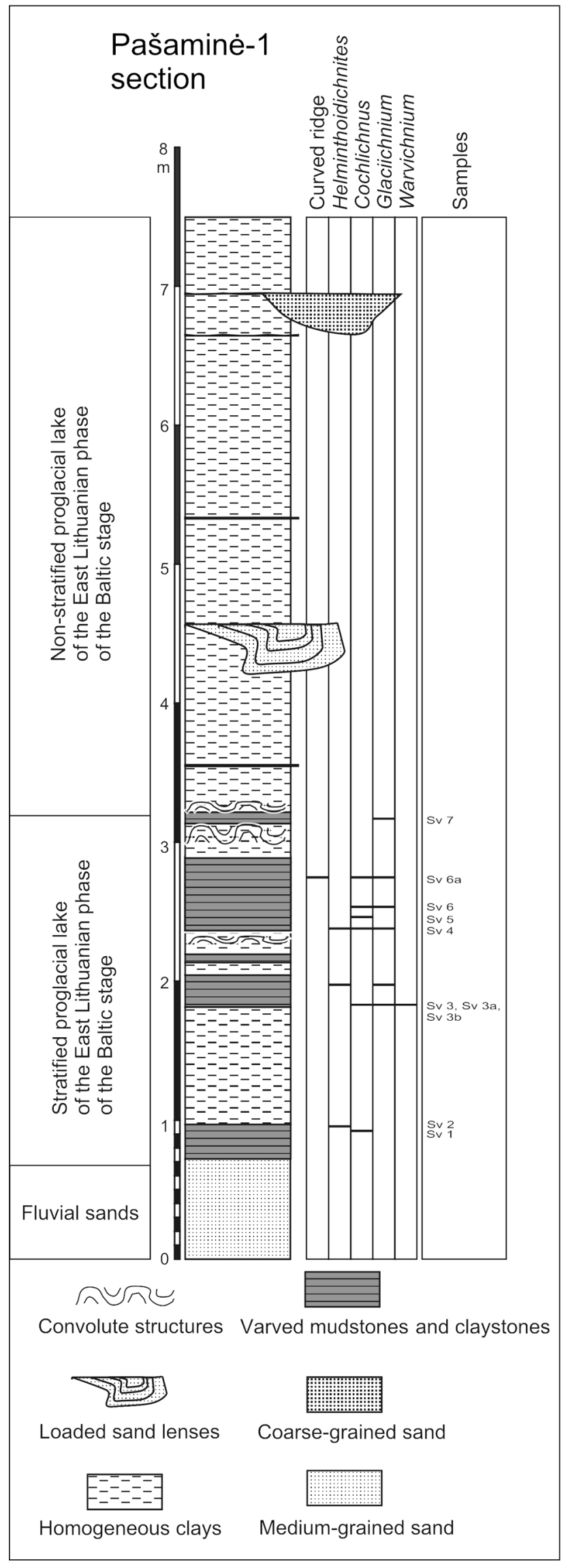

Fig. 2. Distribution of trace fossils in the Pašaminè-1 section

2 pav. Ichnofosilijų pasiskirstymas Pašaminès-1 pjūvyje
(0.70-0.98 m), winter laminae composed of dark brown clay dominate. Summer laminae are composed of light yellowish silty very fine-grained sand or greenish gray silt. Winter laminae decrease in thickness upwards. The varves can be interpreted as distal varves with a tendency to become proximal up the package. Trace fossils occur at a level of 0.96-0.98 m in a silty microlamina splitting laterally into two clay laminae $5 \mathrm{~mm}$ thick. Cochlichnus and Helminthoidichnites have been observed in two laminae.

In the second package (1.80-2.04 m), varved sediments are composed of dark brown clay and greyish yellow silt laminae with dislocations in the lower part. The silt laminae, and to a less extent the clay laminae, display a well expressed microlamination. Some of the microlaminae are less than $0.5 \mathrm{~mm}$ thick. Glaciichnium, Warvichnium, Helminthoidichnites and Cochlich$n u s$ are present in two laminae.

In the third package $(2.35-2.90 \mathrm{~m})$, varved sediments are composed of dark brown clay and laminae of greyish yellow silt, which display microlamination. Trace fossils Glaciichnium, Helminthoidichnites, Cochlichnus and the thin curved ridge have been identified in this laminated interval.

Later in 2005, investigations of the vertical (Pašaminè-2 section) and lateral (in a $215 \mathrm{~m}$ long profile) distribution of trace fossils in glaciolacustrine laminated clay of the Pašamine clay pit were carried out in a more detailed way: some block samples (size $20 \times 15 \times 6 \mathrm{~cm}$ ) were taken from microlaminated intervals for investigations under laboratory conditions. Relatively common trace fossils Cochlichnus, Glaciichnium, Helminthoidichnites and rare Warvichnium and Gordia carickensis were found in the Pašaminè-2 section, which is located about $170 \mathrm{~m}$ to the south from the Pašamine- 1 section. The investigations of lateral distribution of trace fossils in the Pašamine clay pit were carried out over a distance of $215 \mathrm{~m}$ in a $5 \mathrm{~cm}$-thick laminated interval of varved clay, in 43 sites located $5 \mathrm{~m}$ apart. A very large differences of trace fossil composition and abundance was observed on fourteen parting surfaces. Generally, Glaciichnium, Warvichnium, Cochlichnus are abundant and Helminthoidichnites and Gordia carickensis are rare (Uchman et al., in press).

The Balbieriškis 2nd and 3rd sections are located on the left bank of the Nemunas River (Fig. 3), about $0.5 \mathrm{~km}$ north of the small Balbieriškis town $\left(54^{\circ} 32^{\prime} 06^{\prime \prime} \mathrm{N} ; 23^{\circ} 53^{\prime} 16^{\prime \prime} \mathrm{E}\right)$ at an elevation of $92 \mathrm{~m}$ a. s. 1 . The relative height attains about $40 \mathrm{~m}$. These two sections (Balbieriškis 2nd and 3rd) are about $200 \mathrm{~m}$ to the south from the Balbieriškis-1 section which was ichnologically investigated in 2003 (Gaigalas, Uchman, 2004). In the Balbieriškis 2nd and 3rd sections, two horizons of glaciolacustrine laminated clayey sediments occur. They are separated by a $4-5 \mathrm{~m}$ thick bed of the South Lithuanian phase till deposits.

The Balbieriškis-2 section (Fig. 3; interval $8-10 \mathrm{~m}$ ) is $2 \mathrm{~m}$ thick and composed of dark brown varved clays which correlate with the lower unit $(0.63-1.8 \mathrm{~m})$ of the Balbieriškis-1 section (Gaigalas, Uchman, 2004). These sediments originated during the interphasial of the South Lithuania-Middle Lithuania. The distribution of trace fossils in the Balbieriškis-2 section is of the same character as in the Balbieriškis-1 section. Trace fossils Cochlichnus, Helminthoidichnites, Gordia, Glaciichnium and curved ridges occur here. Below the till deposits we observed the lower horizon of glaciolacustrine sediments of the Balbieriškis-3 section 
(Fig. 3; 0.2-3.4 m). These glaciolacustrine sediments were deposited during the interphasial of the East Lithuania - South Lithuania. They are overlain by till deposits of the South Lithuania phase receding glacier. In this section, only three parting surfaces of varves with ichnofossils (Cochlichnus, Helminthoidichnites and Glaciichnium) were found.

The Krūna-1 section (Fig. 4; near Neveronys) is located in the northern part of the Kaunas-Kaišiadoriai glaciolacustrine basin, in the clay pit of the Palemonas ceramic plant (54'55'58” N; $24^{\circ} 07^{\prime} 48^{\prime \prime} \mathrm{E}$ ) at $68 \mathrm{~m}$ a. s. 1 . The clay pit was started to exploit in 2004. This section of glaciolacustrine laminated sediments reflects the sedimentation conditions that existed in the northern part of the Kaunas-Kaišiadorys proglacial lake during the Middle Lithuanian phasial of the Baltija stadial of the Nemunas Glaciation about 14,000 years BP. According to the lithology and character of lamination, the glaciolacustrine sediments can be subdivided into two units: the lower unit composed of dark brown varved clay with intercalations of silty clay or silt,

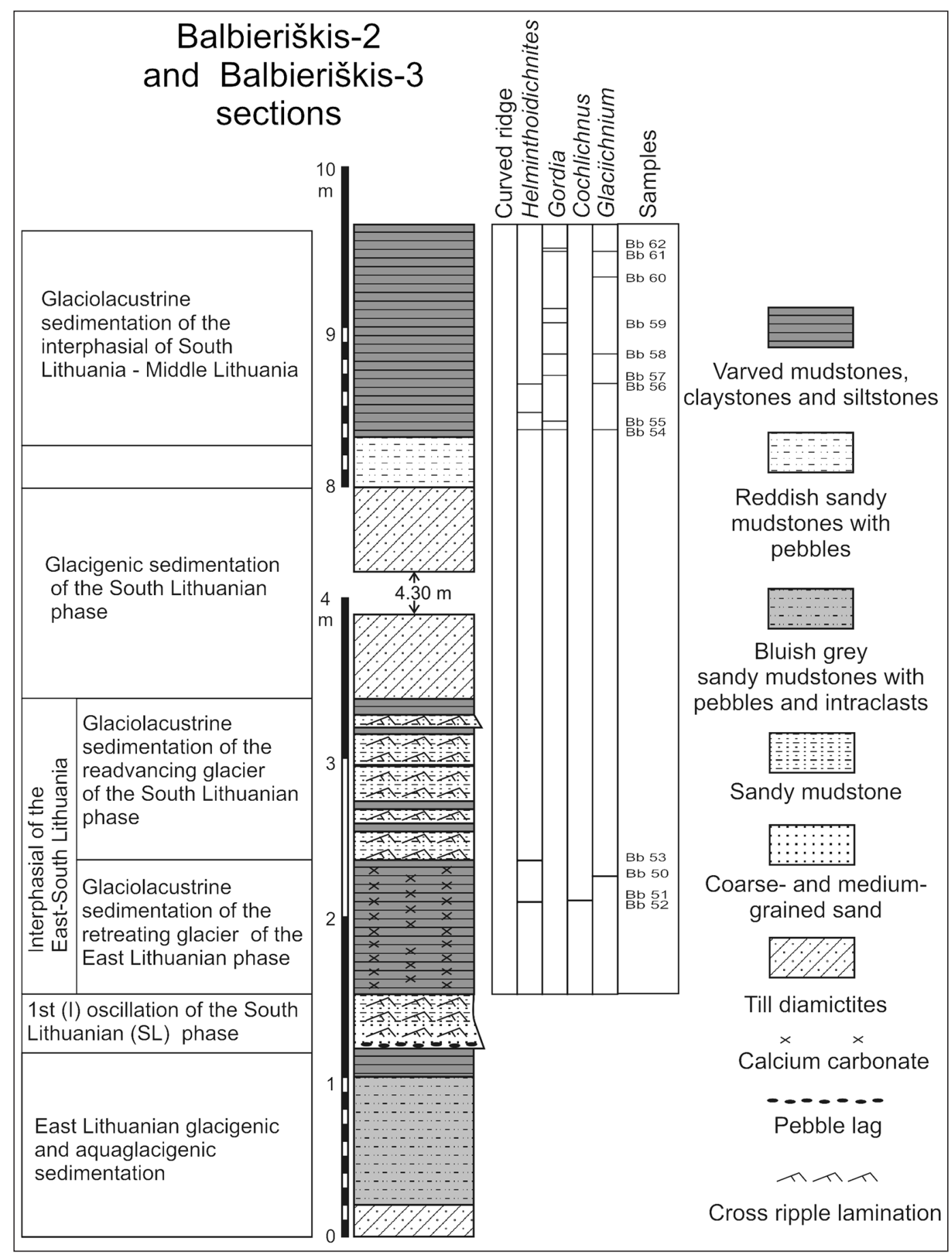

Fig. 3. Distribution of trace fossils in the Balbieriškis-2 and Balbieriškis-3 sections

3 pav. Ichnofosilijų pasiskirstymas Balbieriškio atodangos 2-ame ir 3-iame pjūviuose 


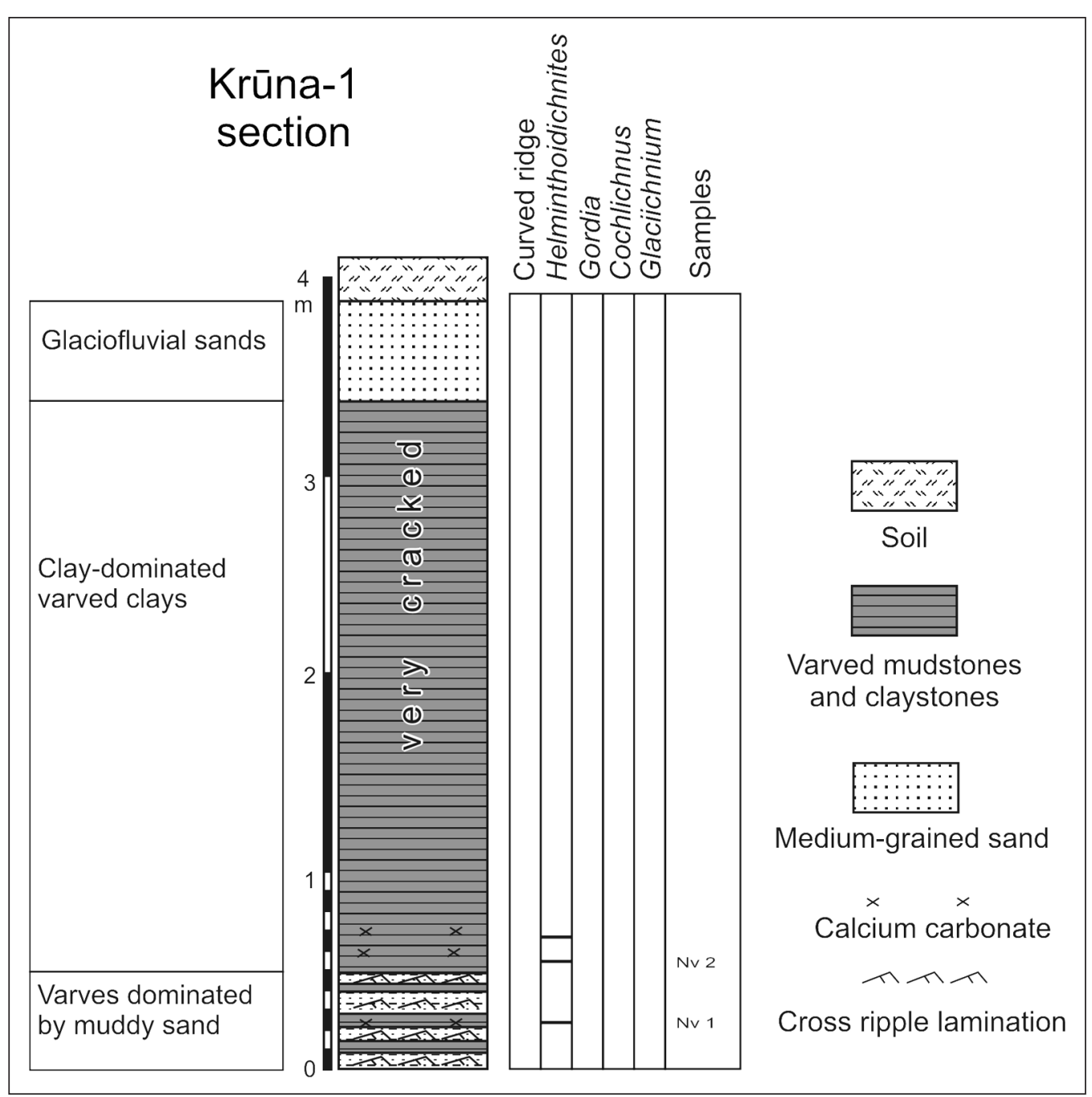

Fig. 4. Distribution of trace fossils in the Krūna-1 section 4 pav. Ichnofosilijų pasiskirstymas Krūnos-1 pjūvyje

and the upper unit composed of reddish brown massive mottled clay with lenses and spots of bluish grey clay (Kazakauskas, 2001). In the Krūna-1 section, glaciolacustrine sediments are up to $4 \mathrm{~m}$ thick. The lower unit (Fig. 4, 0-0.5 m) is composed of dark brown varved clay. Only the upper part of these units was investigated. Its lower part, which reflects the initial stage of proglacial lake formation during climate warming and the glacier retreat, is covered below the bottom of the clay pit. The upper unit (Fig. 4, 0.5-3.4 m) is composed of brown, very cracked, massive, mottled clays, which reflect the more or less stable conditions near the margin of the glacier with some local oscillations. The medium-grained sand layer (Fig. 4; 3.4-3.9 m), overlying the massive clay bed, reflects the final stage of the proglacial lake and the glacier retreat. The trace fossils were observed in varved clays of the lower unit (in the interval 0.2-0.75 m). Only Helminthoidichnites were identified here. In the middle part (interval 3.2-5.9 m) of the Girininkai section of the same Kaunas-Kaišiadorys glaciolacustrine basin, which is located in southern part of the basin about $22 \mathrm{~km}$ to the southwest from the Krūna-1 section, trace fossils are very diverse and abundant (Cochlichnus, Helminthoidichnites, Gordia, Glaciichnium) (Gaigalas, Uchman, 2004).

The Tauragè-1 section (Fig. 5; near Tauragè) is located in the western part of the Jūra-Šešupe glaciolacustrine basin, in the clay pit of the Taurage ceramic (AB Taragès keramika) plant

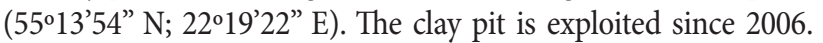
This section reflects the conditions during the interphasial of the South Lithuanian-Middle Lithuanian of the Baltija stadial of the Nemunas Glaciation about 14,000 years BP. The development of the Jūra-Šešupe basin depended on the degradation pattern of the Lower Nemunas lobe of the ice cover. The following climatic evolutionary stages have been determined: (1) a short climatic warming with an oscillatory retreat of the glacier, characterized by sedimentation of distinctly laminated clays with prevailing winter laminae, (2) more stable climatic conditions characterized by sedimentation of indistinctly laminated clays, (3) climatic warming with a clear seasonality characterized by sedimentation of laminated silty and calcareous clays (Kazakauskas, Gaigalas, 2000). The Taurage -1 section is $6.2 \mathrm{~m}$ thick. Till deposits, which extend 1-2 $\mathrm{m}$ below the bottom of the clay pit, have not been observed. According to the lithology and character of lamination, the Taurage- 1 section can be subdivided into three units which reflect different sedimentation conditions. The lower unit, below the bottom of the quarry, was not investigated, It is composed of glaciolacustrine layers intercalated with till deposits; it reflects the initial stage of proglacial lake formation near the margin of the glacier.

The middle unit (Fig. 5; 0-2.2 m) is composed of varved sediments (mostly silts and clays) intercalated with layers of dark 


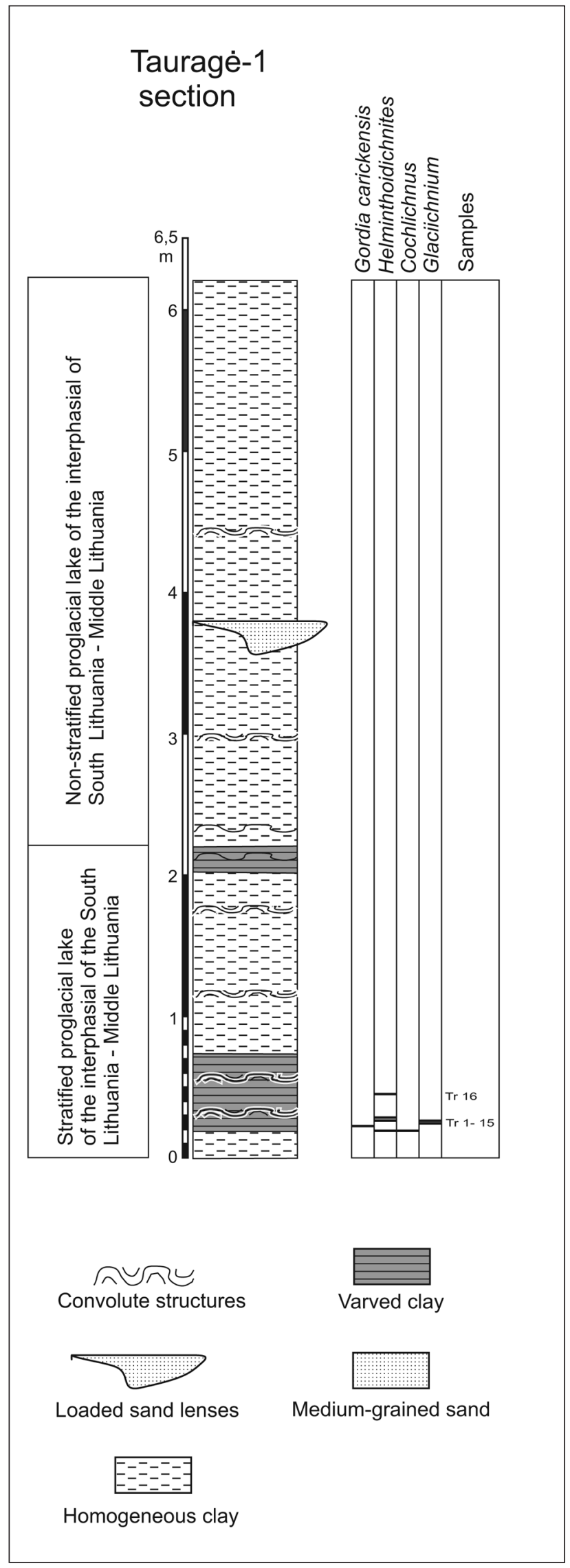

Fig. 5. Distribution of trace fossils in the Tauragè-1 section

5 pav. Ichnofosilijų pasiskirstymas Tauragès-1 pjūvyje brown clay with laminae of greenish calcareous silt or light brown silt. The middle unit originated in a stratified proglacial lake with a contact to the glacier as can be supposed from the presence of dropstones in varves and deformations of lamination. Trace fossils Cochlichnus, Helminthoidichnites, Gordia carickensis and Glaciichnium were found in eight parting surfaces of the varves. In the interval $0.23-0.31 \mathrm{~m}$, a microlamination in brown clay and light-yellow calcareous silt occurs. Because of the bad splitting of the microlaminae, a block sample (size $20 \times 15 \times 6 \mathrm{~cm}$ ) was investigated in the laboratory after some drying for $2-3$ nights at a temperature of $20^{\circ} \mathrm{C}$. As a result, six parting surfaces of laminae with trace fossils in a $6 \mathrm{~cm}$ thick microlaminated interval (Fig. 6) were found. They contained Cochlichnus, Helminthoidichnites, Gordia carickensis and Glaciichnium.

The upper unit $(2.20-6.40 \mathrm{~m})$ is composed of dark brown massive clay with local convolute deformations and with sand lenses. It reflects the late stage of sedimentation in a non-stratified proglacial lake with encroaching fluvial sedimentation.

\section{SYNOPSIS OF TRACE FOSSILS}

Four ichnospecies of four ichnogenera have been distinguished in the investigated sections. They include Cochlichnus anguineus Hitchcock, 1858, Glaciichnium liebegastensis Walter, 1985, Gordia isp. and Helminthoidichnites isp. The illustrated specimens are housed at the Institute of Geology and Geography (collection prefix $\operatorname{Tr}$ for Taurage section) and Vilnius University in Vilnius (collection prefix Sv for Pašaminè-1 section, $\mathrm{Bb}$ - for Balbieriškis 2 and 3 sections, and $\mathrm{Nv}$ - for Krūna-1 section).

Cochlichnus anguineus Hitchcock 1858 (Fig. 7 A) is a very thin meandering groove on the upper parting surfaces or a hypichnial meandering ridge on the lower parting surfaces, which display regular first-order sinuous meanders. The grooves or ridges are $0.2-0.6 \mathrm{~mm}$ wide. In some well preserved specimens, the ridges display local corrugations suggesting a meniscate internal structure. The wavelength of the sinuous meanders ranges between 1.5-5.5 mm and the amplitude between 0.5 and $2 \mathrm{~mm}$. Some specimens display a slightly helical geometry in which elevated and depressed turns alternate on the bedding surface. The amplitude / wavelength ratio varies from specimen to specimen. In some specimens it is very low (stretched forms or the Heftisch pattern of Walter and Suhr, 1998).

The type material of Cochlichnus anguineus, the type ichnospecies of Cochlichnus, derives from the Triassic of New England and is known only from drawings (Hitchcock, 1858). Most examples of this ichnospecies are known from the Palaeozoic (e. g., Fillion, Pickerill, 1990; Głuszek, 1995; Walter, Hofmann, 2001). Rindsberg (1994) restricted only surface traces to Cochlichnus, and the subsurface forms included in a new ichnogenus Cymatulus. This idea was criticized by Stanley and Pickerill (1998) who regarded Cymatulus as a junior synonym of Cochlichnus.

Different producers of non-marine Cochlichnus are suggested in the literature. Hitchcock (1858) referred it to annelids and Andersson to chironomid dipterous insects, including Chironomus motilator (see also Emerson, 1898; Tarr, 1935; Walter, 1986). Toula (1908) regarded Cochlichnus to be produced by insect larvae. It was proven that they can be biting midge 


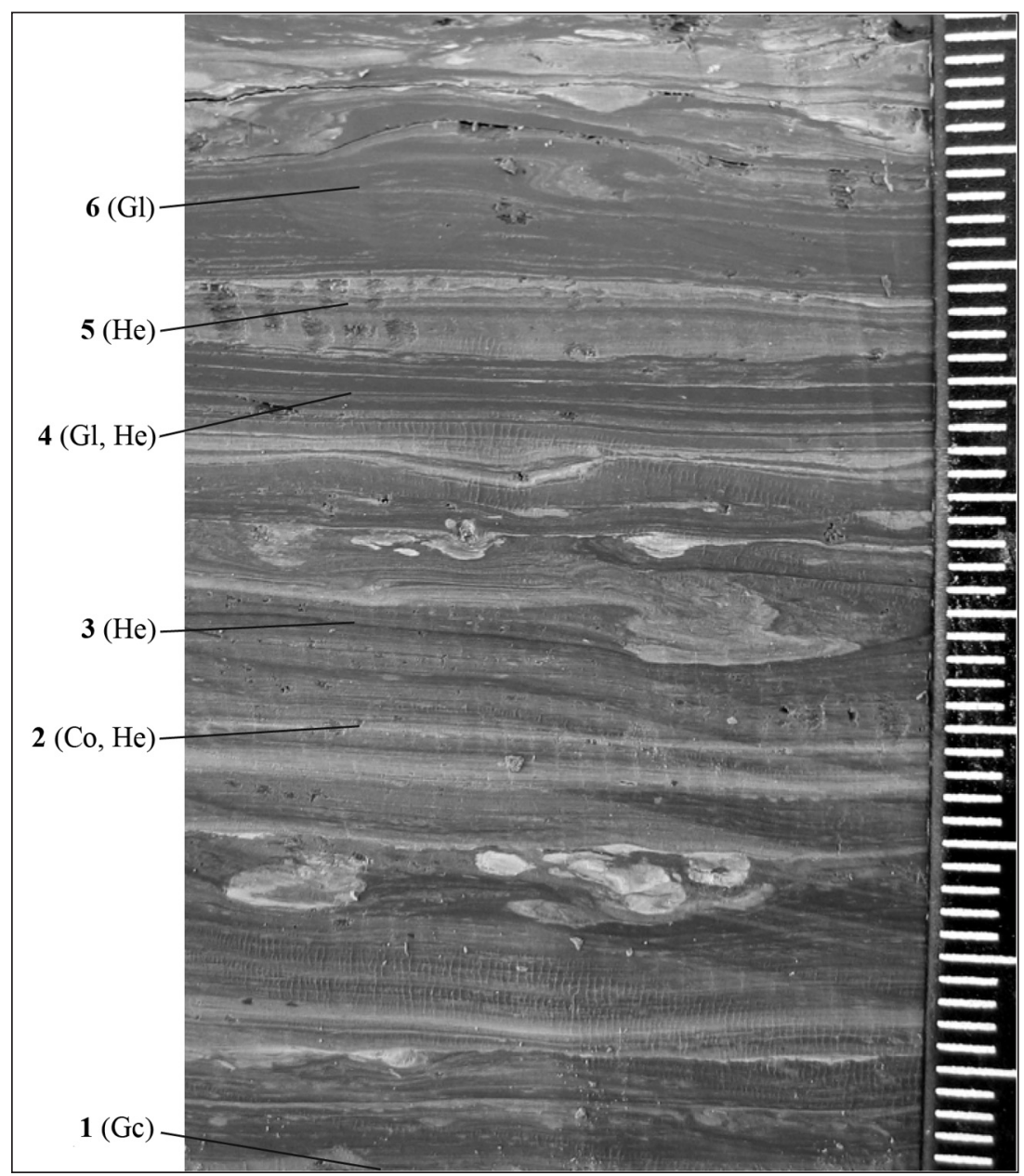

Fig. 6. Trace fossils from a $6 \mathrm{~cm}$ thick microlaminated interval (at a depth of $0.24-0.30 \mathrm{~m}$ ) of Taurage-1 section. GI - Glaciichnium, He - Helminthoidichnites, Co - Cochlichnus, $\mathrm{Gc}$ - Gordia carickensis

6 pav. Tauragės-1 pjūvio $6 \mathrm{~cm}$ storio mikrosluoksniuoto intervalo $(0,24-0,30 \mathrm{~m}$ gylyje) ichnofosilijos. Gl - Glaciichnium, He - Helminthoidichnites, Co - Cochlichnus, Gc - Gordia carickensis
(Ceratopogonidae family) larvae (Michealis, 1972) or dipteran larvae (Therevidae family) (Metz, 1987). Other authors referred Cochlichnus to nematode trails (Moussa, 1970; Chamberlain, 1975; Metz, 1998). This view is confirmed by experiments (Sandstedt et al., 1961; Rode, Staar, 1961), but the nematode traces are very small (mean wavelength less than $0.5 \mathrm{~mm}$ ), i. e. much smaller than in the described material. Walter and Hofmann (2001) underlined Cochlichnus occurrence in extreme environments which fits well proglacial lakes.

Glaciichnium liebegastensis Walter 1985 (Fig. 7 C, D) occurs as a straight to winding, differently preserved trackway, which is $2-5 \mathrm{~mm}$ wide and composed of sets of imprints seen as $0.1-0.5 \mathrm{~mm}$ wide and $0.5-2.5 \mathrm{~mm}$ long, straight or curved furrows or ridges. They are sub-parallel in the central part and oblique on the sides. The oblique elements are concordantly inclined to the main axis of the trace fossil at an angle up to $45^{\circ}$. They form a V-like pattern. The oblique bars can be subdivided into three segments. In some specimens only the sub-parallel bars are preserved. In others, a $0.8-1 \mathrm{~mm}$ wide central groove or ridge and side oblique elements are present. The grooves can be bounded by a disrupted levee.

The geometry of Glaciichnium is typical of arthropod trackways whose preservation depends on the substrate properties and the level of observations; the leg impressions are expressed in different ways on different laminae, and part of them are recorded as undertracks, i. e. impressions of appendages on lower laminae below the real footprint (cf. Goldring, Seilacher, 1971). Some of them display body drag marks seen as the central furrow.

Glaciichnium liebegastensis is interpreted as a trackway of isopods of the genus Asellus as pointed out by experiments with water hoglouse (Asellus aquaticus) (Schwarzbach, 1938; Gibbard, Stuart, 1974). This crustacean is a typical animal of glacial lakes, feeding on algae and plant detritus and able to survive temporary freezing (Gibbard, Dreimanis, 1978).

Gordia carickensis (Smith, 1909) occurs as about $0.1 \mathrm{~mm}$ wide densely looped grooves or ridges. Some segments are more stretched and show a winding course. So far it was described as Mermia carickensis Smith (1909), but the differences between Mermia and Gordia are not sufficient to separate them at the ichnogenus level (Pickerill, Peel, 1991; Uchman et al., in press). Gordia carickensis can be produced by minute arthropods such as Walker (1985), horsehair worms (Nematophora) (Chamberlain, 1975; Buatois, Mángano, 1993a) or chironomid midge larvae (cf. Duck, McManus, 1984).

Gordia isp. (Fig. 7 E) is a smooth horizontal ribbon on parting surfaces forming irregular loops. It is $0.35-1 \mathrm{~mm}$ wide, and loops are about 3-8 mm wide. Gordia Emmons, 1844 is separated from Helminthoidichnites Fitch, 1850 which displays a weaker tendency to looping (Hoffmann, 1990); however, transitional forms are not rare in the analysed material. Gordia occurs in many marine and non-marine facies 

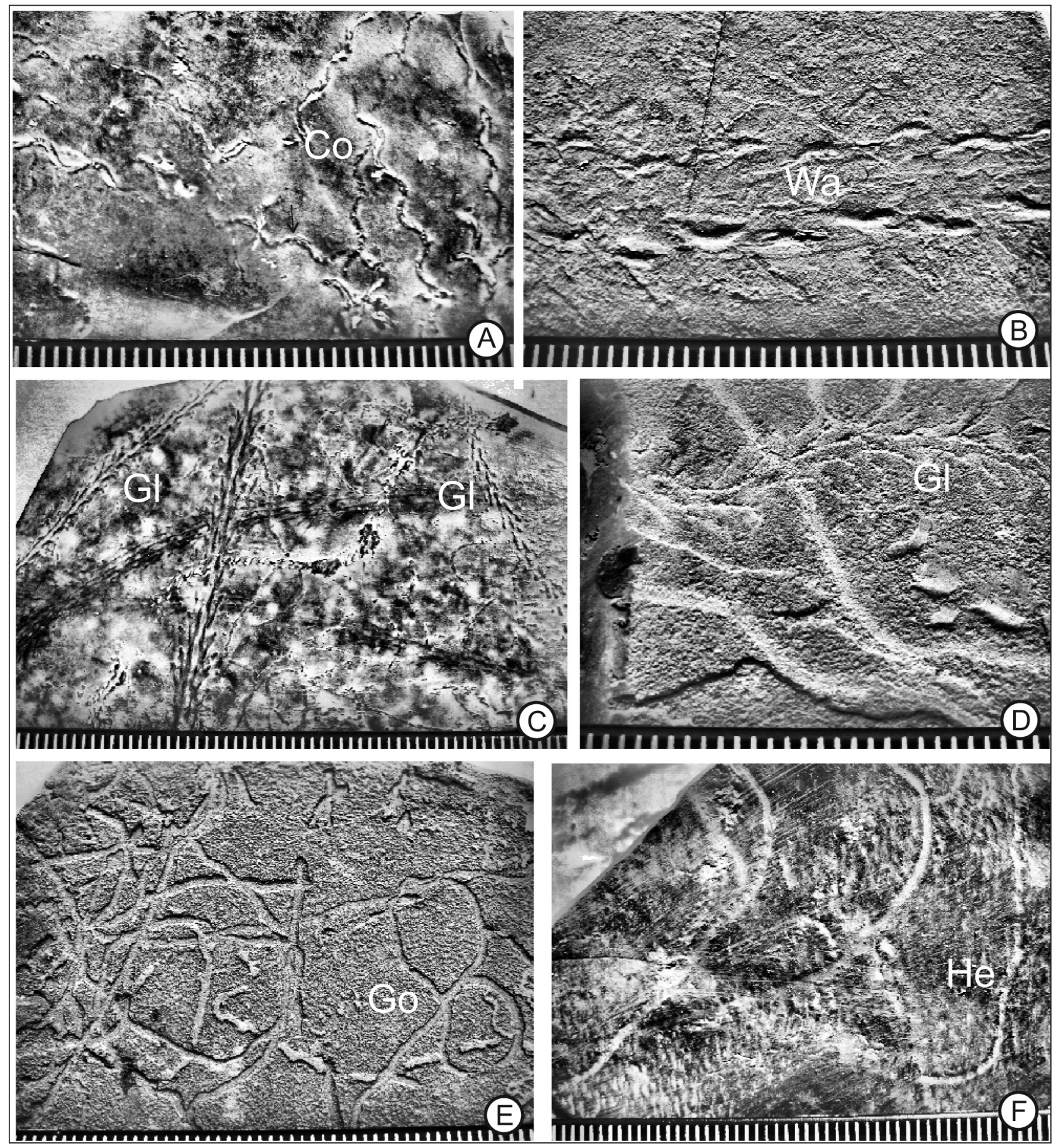

Fig. 7. Selected trace fossils from the study sections. Millimetre scale.

A - Cochlichnus anguineus (Co), SV-3 (lower parting surface); B - Warvichnium ulbrichi (Wa), Sv-3a (upper parting surface); C - Glaciichnium liebegastensis (Gl), Sv-3b (lower parting surface); D - Glaciichnium liebegastensis (GI), Bb-61 (upper parting surface); E - Gordia isp. (Go), Bb-57 (upper parting surface), F- Helminthoidichnites isp. (He), Tr-15 (lower parting surface)

7 pav. Tyrinètų pjūvių ichnofosilijos. Milimetrinè skalè.

A - Cochlichnus anguineus (Co), SV-3 (apatinio sluoksnelio pavirš̌ius); B - Warvichnium ulbrichi (Wa), SV-3a (viršutinio sluoksnelio paviršius); C - Glaciichnium liebegastensis (Gl), SV-3b (apatinio sluoksnelio pavirš̌ius); D - Glaciichnium liebegastensis (GI), Bb-61 (viršutinio sluoksnelio paviršius); $E$ - Gordia isp. (Go), Bb-57 (viršutinio sluoksnelio paviršius); $F-$ Helminthoidichnites isp. (He), Tr-15 (apatinio sluoksnelio paviršius)

(e. g., Pickerill et al., 1984) and is common in lacustrine deposits (Pickerill, 1987; Buatois, Mángano, 1990; Aceñolaza, Buatois, 1991). In wet mud, looping trails are produced by the millipede Julus (Boy, 1976, Fig. 41b; Rolfe, 1980, p. 135, Fig. 5A) crane fly larvae (Ahlbrandt et al., 1978, Fig. 1M) and pulmonate gastropods (e. g., Abel, 1935, p. 209). In fresh waters, such traces can be produced by moving and / or feeding insect lar- vae (Gibbard, Dreimanis, 1978) or gastropods (Gibbard, Stuart, 1974; Merta, 1980).

Helminthoidichnites isp. (Fig. 7 F) occurs as an irregularly winding horizontal, mostly smooth ribbon preserved on both parting surfaces, rarely ridges on the upper parting surface or grooves on the lower parting surface. Most of them are $0.5-1 \mathrm{~mm}$ wide. The ribbons are lighter than the surrounding rock. 


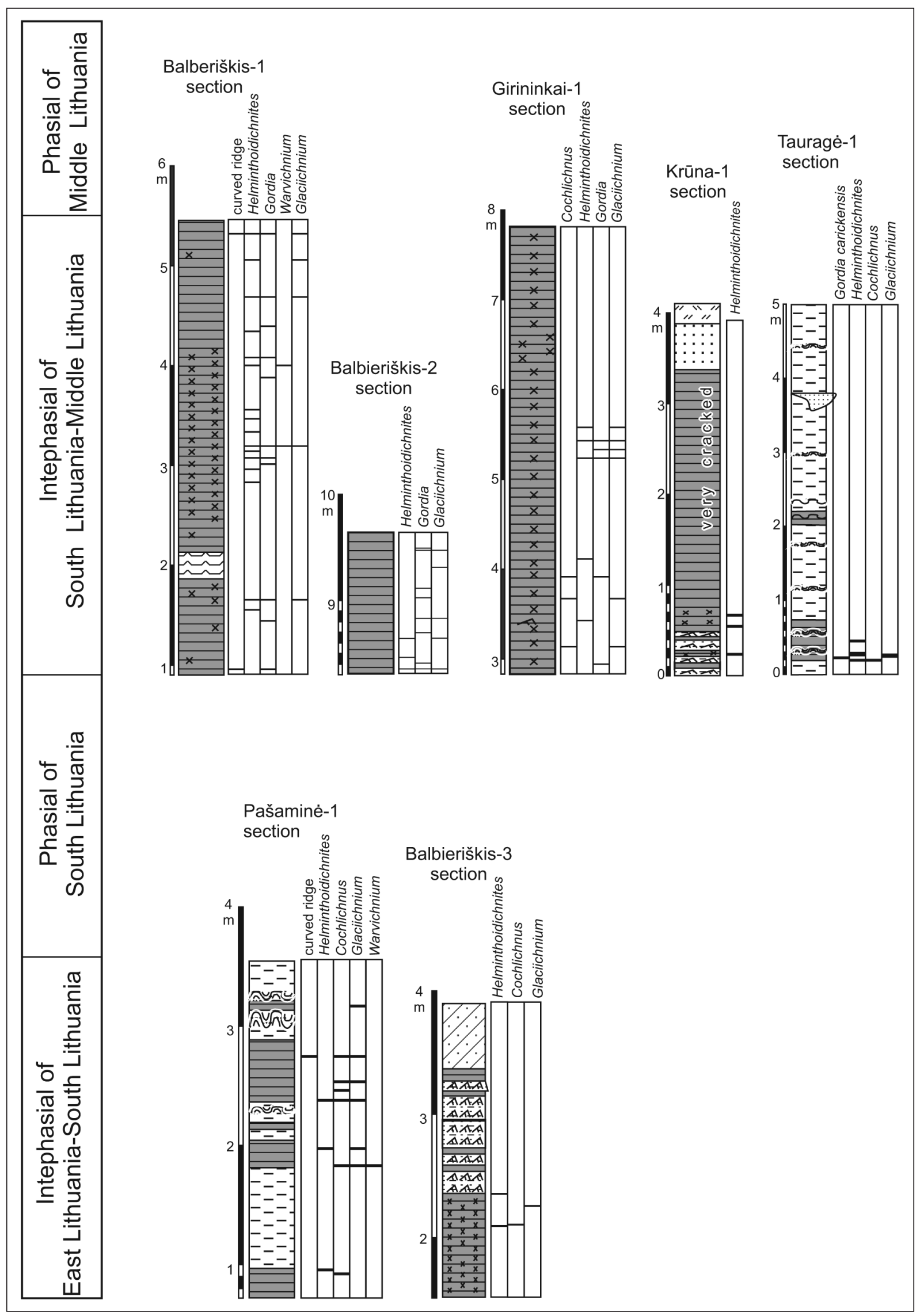

Fig. 8. Distribution of the study section against the stratigraphic scheme of the Nemunas Glaciation. For legend, see Figs. 2-5

8 pav. Nemuno apledejjimo Baltijos stadijos Rytų Lietuvos-Pietų Lietuvos ir Pietų Lietuvos-Vidurio Lietuvos tarpfazialai. Sutartinius ženklus žiürèti 2-5 pav. 
Helminthoidichnites Fitch, 1850 displays only occasional loops, whereas in Gordia Emmons, 1844 loops are the most characteristic feature. In contrast to these genera, Helminthopsis has no loops (the differences between Helminthoidichnites and Gordia were analysed by Hofmann and Patel (1989) and Hofmann, 1990). However, in some specimens from the analysed material, there are transitions from Gordia to Helminthoidichnites. This suggests that these trace fossils were produced by the same tracemaker.

Helminthoidichnites are known from marine Precambrian (Narbonne, Aitken, 1990) and the latter from marine and nonmarine settings up to the Pleistocene (Uchman et al., 2007). In non-marine environments, it is interpreted as a probable nematophore or insect larvae trail (Buatois et al., 1997). A. Uchman suggested arthropods to be producers on the basis of sets of oblique striae seen in some specimens ((Uchman et al., in press), see also Spur D of Köwing, 1954, which was referred to small crayfish ("kleinen Krebs" by Murawski, 1964, Fig. 5K4)).

Warvichnium ulbrichi Walter 1985 (Fig. 7 B) displays a central straight to winding part and symmetric or asymmetric side parts. The central part, $2-7.5 \mathrm{~mm}$ wide, is composed of a series of imbricated, concordantly open, narrow arcs located 3-9 mm apart. In some specimens, the central part displays a double series of small pits, located 3-4 mm apart on each side of the series, or a double series or short, slightly arcuate bars parallel or sub-parallel to the trace fossil course. The side parts present only in some specimens, are composed of oblique bars $10 \mathrm{~mm}$ long, $27 \mathrm{~mm}$ apart, located $2-5 \mathrm{~mm}$ aside from the central part. Warvichnium is interpreted as an insect trackway (Walter, 1985).

Curved ridges are simple arcuate ridges on the lower parting surface, about $0.3 \mathrm{~mm}$ wide. The ridge displays irregular enlargements and disruptions. The longer axis of these disruptions is elongated according to the ridge course.

The disruptions and constrictions suggest pulsatory movements of the tracemaker. It is not excluded that this trace fossil was produced by a pulsatory movement of a small mollusc foot.

\section{DISCUSSION}

The trace fossil assemblage from the studied varved clays belongs to the Mermia ichnofacies which is typical of lakes (Buatois, Mángano, 1995). The composition and abundance of particular ichnotaxa varies from section to section (Fig. 8). For instance, Cochlichnus is very common in the Pašaminè-1 and Pašaminè-2 sections, but it was not found in the Balbieriškis-1 section. Warvichnium is relatively common in the Pašaminè-1 and Pašaminè- 2 sections, very rare in the Balbieriškis- 1 section and absent in the remaining sections. The Balbieriškis-1 and Pašamine- 2 sections contain five ichnotaxa and the Krūna-1 section only one ichnotaxon. These differences can be caused by at least three factors: (1) the composition of trace fossil assemblages depends on the ecological zone of the lake - the cursichnia (Glaciichnium) ichnocoenosis is typical of shallower (metalimnion) zones and the Cochlichnus ichnocoenosis is typical of deeper zones (hypolimnion) (see Walter, 1985; Walter, Suhr, 1998), (2) every proglacial lake has is own unique faunal assem- blages, (3) trace fossils display a patchy distribution (Uchman et al., in press) and their record in a narrow vertical section is fragmentary. The first factor should be applied with caution because members of both ichnocoenoses occur in adjacent laminae, and it is impossible to relate them to different bathymetric zones but rather to the worsening or improving of ecological conditions, i. e. Cochlichnus indicates more stressful conditions than do Glaciichnium or Warvichnium (Uchman et al., 2007). The third factor, i. e. the possible fragmentary observations of trace fossils in narrow vertical sections, has some limitations, because differences in the abundance of some ichnotaxa among the sections are striking and the abundant ichnotaxa cannot be overlooked. The second factor, i. e. the unique faunal assemblages in the lakes, seems to be very important. The lakes were probably very ecologically sensitive habitats influenced by many physical and biological factors which controlled the composition and abundance of trace makers.

Only some laminae or packages of laminae contain trace fossils. In some sections, quite thick (decimetre to over a metre) lamina packages are barren of trace fossils. It is not excluded that some ichnotaxa will be found in these packages as a result of further investigations on block samples in the laboratory, but the presence of barren laminae will not be eliminated. Probably, the laminae were not colonized at all because of too severe ecological conditions. Therefore, alternation of colonized and non-colonized packages can indicate oscillations of ecological conditions, which can be related to the short-term climatic fluctuations. In a broader sense, varved clays bearing trace fossils can indicate improvements of climatic conditions related to the interphasials or interoscillations of the Baltija stadial of the Nemunas Glaciation in our case. The fact of formation of proglacial lakes is related to the ice-sheet retreat from Lithuania and is an evidence of climatic condition improvements itself. The presence of trace fossils in varved clays of proglacial glaciolacustrine basins of the Upper Pleistocene reflects the warmer climate of the East Lithuanian-South Lithuanian interphasials and the South Lithuanian-Middle Lithuanian of the Baltija (Pomeranian) stadial of the Nemunas (Vistulian) Glaciation (Fig. 8). The massive clays can be an evidence of even better ecological conditions, where clays are totally bioturbated. Otherwise, it is hard to explain their massive structure without any primary lamination. Trace fossils are not preserved there because all biogenic structures are obliterated by bioturbation in the water-saturated, soupy sediment near the bottom.

\section{CONCLUSIONS}

In general, the proglacial lake varved clay sediments of the Last Glaciation were formed in extreme conditions of cold arctic climate. The warmer climate of the interphasials or interoscillations in the sequence of lacustrine sediments is marked by occurrence of trace fossils which include Gordia, Helminthoidichnites, Glaciichnium and rare Cochlichnus, Warvichnium. These trace fossils are typical of the Mermia ichnofacies. They can be used for recognition of glaciolacustrine-lacustrine subfacies and climatic changes in glaciated regions of North Europe during the Late Pleistocene. 


\section{ACNOWLEDGEMENTS}

The research was supported by the Lithuanian State Science and Studies Foundation (grants Nos. T-35/07 and T-37/08). A. U. was supported by the Jagiellonian University (BW funds).

\section{References}

1. Abel O. 1935. Vorzeitliche Lebensspuren. Jena: Gustav Fischer. $644 \mathrm{p}$.

2. Aceñolaza F. G., Buatois L. A. 1991. Trazas fosilies del Paleozoico superior continental Argentina. Ameghiniana. 28. 89-108.

3. Ahlbrandt T. S., Andrews S., Gwynne D. T. 1978. Bioturbation of eolian deposits. Journal of Sedimentary Petrology. 48. 839-848.

4. Andersson G. 1897. Den Centraljämtska issjön. Sveriges Geologiska Undersökning. Serie C. 166. 1-76.

5. Ashley G. M. 1975. Rhythmic sedimentation in glacial lake Hitchcock, Massachusetts - Connecticut. In: Jopling A. V., McDonald B. C. (eds.). Glaciofluvial and glaciolacustrine sedimentation. Society of Economic Paleontologists and Mineralogists, Special Publication. 23. 304-320.

6. Banerjee J. 1973. Sedimentology of Pleistocene glacial varves in Ontario, Canada. Geological Survey of Canada. Bulletin. 226. 1-44.

7. Basalykas A. 1960. On varved deposits of glacio-lacustrine character in river valleys. In: Gudelis V. (ed.). Collectanea Acta Geologica Lithuanica, Collected Papers for the 21st Session of the International Geological Congress. Vilnius. 283-287.

8. Basalykas A. 1962. Pakraštiniai ledyniniai dariniai ir kai kurios pastabos Lietuvos TSR teritorijos deglaciacijos klausimu. Geografija ir geologija. 2.

9. Basalykas A. 1965. Lietuvos TSR fizinè geografija. T. 2. Vilnius: Mintis. 496.

10. Басалыкас А. 1967. О приледниковых водоемах Южной Прибалтики. История озер Северо-Запада. Ленинград: Наука. 17-33.

11. Basalykas A. 1981. Geomorfologinis žemèlapis. Lietuvos TSR atlasas. VGKV. M. 215 p.

12. Benner J. S., Ridge J. C. 2006. Piscine trace fossils from Late Wisconsinan glacial varves, Vermont, USA: Stratigraphic, paleoecologic and paleobiogeographic implications. Geological Society of America Abstracts with Programs. 36(5). 287.

13. Benner J., Ridge J. 2007. A review of Pleistocene glaciolacustrine ichnology and its potential as a high-resolution paleoecological record during times of rapid climate change, with examples from the Late Pleistocene of New England, USA. Limneology: tales of an evolving Earth. 4th International Limneology Congress, ILIC 2007, Barcelona, Programme and abstract book. Planetearth, Earth Sciences for Society. Barcelona. 41-42.

14. Benner J. S., Ridge J. C., Taft N. K. 2008. Late Pleistocene freshwater fish (Cottidae) trackways from New England (USA) glacial lakes and a reinterpretation of the ichnogenus Broomichnium Kuhn. Palaeogeography, Palaeoclimatology, Palaeoecology. 260. 375-388.
15. Benner J. S., Taft N. K., Ridge J. C. 2006. Trackways produced by fish: Implications of substrate-contact behavior by fish recorded in trace fossils from Late Pleistocene glacial varves, New England, USA. Geological Society of America Abstracts with Programs. 38(7). 537.

16. BoyJ. A. 1976. Überblick über die Fauna des saarspfalzischen Rotliegenden (Unter-Perm). Mainzer Geowissenschftliche Mitteilungen. 5. 3-85.

17. Buatois L. A., Jalfin G., Aceñolaza F. G. 1997. Permian non marine invertebrate trace fossils from southern Patagonia, Argentina, ichnologic signatures of substrate consolidation and colonization sequences. Journal of Paleontology. 71. 324-336.

18. Buatois L. A., Mángano M. G. 1990. Una asociacion de trazos fosilies de Carbonico lacustre del area de Las Jumes, Catamarca, Argentina: Su comparacion con la ichnofacies de Scoyenia. 5 Congreso Argentino de Paleontologia y Biostratigrafia. Serie Correlación. Geologica. 7. 77-81.

19. Buatois L., Mángano M. G. 1993. Trace fossils from a Carboniferous turbiditic lake: implications for the recognition of additional nonmarine ichnofacies. Ichnos. 2. 237-258.

20. Buatois L. A., Mángano M. G. 1995. The paleoenvironmental and paleoecological significance of the lacustrine Mermia ichnofacies: an archetypical subaqueous nonmarine trace fossil assemblage. Ichnos. 4. 151-161.

21. Buatois L. A., Mángano G. M. 1998. Trace fossil analysis of lacustrine facies and basins. Palaeogeography, Palaeoclimatology, Palaeoecology. 140. 367-382.

22. Buatois L. A., Mángano M. G. 2007. Invertebrate ichnology of continental freshwater environments. In: Miller W. (ed.). Trace Fossils Concepts, Problems, Prospects. Amsterdam: Elsevier. 285-323.

23. Chamberlain C. K. 1975. Recent Lebensspuren in non-marine environments. In: Frey R. W. (ed.). The Study of Trace Fossils. New York: Springer. 431-458.

24. Dahm D. and Otto W. 1953. Über Lebensspuren in Bändertonen Nordwestdeutschlands. Freiberger Forschungshefte. C, 5. 39-40.

25. Duck R.W., McManus J. 1984. Traces produced by chironomid larvae in sediments of an ice-contact proglacial lake. Boreas. 13. 89-93.

26. Emerson B. K. 1898. Geology of Old Hempshire County, Massachusetts comprising Franklin, Hempshire, and Hampden counties. Unites States Geological Survey Monograph. 29. 1-790.

27. Fillion D., Pickerill R. K. 1990. Ichnology of the Upper Cambrian? to Lower Ordovician Bell Island and Wabana groups of eastern Newfoundland, Canada. Palaeontographica Canadiana. 7. 1-119.

28. Fliri F., Hilscher, H. Markengraf, V. 1971. Weitere Untersuchungen zur Chronologie der alpinen Vereisung (Bändertonen von Baumkirchen, Inntal, Nordtirol). Zeitschrift für Gletscherkunde and Glazialgeologie. 7. 5-24.

29. Fuchs M. 1988. Über einen Neufund von Arthropodenfährten in elsterkalzeitlichen Bänderschluffen des Raumees Fürstenwalde / Spree. Fundgrube. 24. 52-54.

30. Gaigalas A. 1994. On palaeogeography of Late Pleistocene in the Lithuania. Acta Universitatis Nicolai Copernici. Geografia. 27. 182-194. 
31. Gaigalas A., Uchman A. 2004. Trace fossils form the Upper Pleistocene varved clays S of Kaunas, Lithuania. Geologija. 45. 16-26.

32. Galvydyte D, 1958. Preliminariniai duomenys apie Žemaičių aukštumos limnoglacialinius baseinus ir jų terasas. Geografinis metraštis. 1. Vilnius. 297-307.

33. Garunkštis A. 1961. Vidurio Lietuvos limnoglacialinio baseino krantinių darinių klausimu. Lietuvos TSR Mokslu akademijos darbai. B serija. 3(26). Vilnius.

34. Gibbard P. L. 1977. Fossil tracks from varved sediments near Lammi, South Finland. Bulletin of the Geological Society of Finland. 49. 53-57.

35. Gibbard P. L., Dreimanis A. 1978. Trace fossils from late Pleistocene glacial lake sediments in southwestern Ontario, Canada. Canadian Journal of Earth Sciences. 15. 1967-1976.

36. Gibbard P. L., Stuart A. J. 1974. Trace fossils from proglacial lake sediments. Boreas. 3. 69-74.

37. Głuszek A. 1995. Invertebrate trace fossils in the continental deposits of an Upper Carboniferous coal-bearing succession, Upper Silesia, Poland. Studia Geologica Polonica. 108. 171-202.

38. Goldring R., Seilacher A. 1971. Limulid undertracks and their sedimentological implications. Neues Jahrbuch für Geologie und Paläontologie. Abhandlungen. 137. 422-442.

39. Gudelis V., Mikaila V. 1960. The largest glacio-lacustrine basins of Lithuania and their significance for geochronology and palaeogeography of the Late-Glacial period. In: Gudelis V. (ed.). Collectanea Acta Geologica Lithuanica, Collected Papers for the 21st Session of the International Geological Congress. Vilnius. 251-269.

40. Hannemann M. 1965. Schreitspuren in elsterkaltzeitlichen Bändertonen der Bohrung XV/61 bei Müllrose (Ostbrandenburg). Geologie. 14. 110-113.

41. Hitchcock E. 1858. Ichnology of New England. A report on the sandstone of the Connecticut Valley, especially its fossil foot marks. Boston: W. White. 220 pp.

42. Hofmann H. J. 1990. Computer simulation of trace fossils with random patterns, and the use of goniograms. Ichnos. 1. 15-22.

43. Hofmann H. J. Patel I. M. 1989. Trace fossils from the type "Etchemian Series" (Lower Cambrian Ratcliffe Brook Formation), Saint John area, New Brunswick, Canada. Geological Magazine. 126. 139-157.

44. Högbom A. G. 1893. Om interglaciala aflagringer i Jemtland. Geologiska Föreningens Förhandlinger. 15. 28-39.

45. Högbom A. G. 1915. Om djurspår i den uppländska ishafsleran. Geologiska Föreningens Förhandlinger. 37. 33-43.

46. Johnson M. D., Addis K. L., Ferber L. R., Hemstad C. B., Meyer G. N., Komai L. T. 1999. Glacial lake Lind, Wisconsin and Minnesota. Bulletin of the Geological Society of America. 111. 1371-1386.

47. Kazakauskas V. 2001. Kauno-Kaišiadorių limnoglacialinio baseino nuosedų storis, paklotinis paviršius ir litofacijos. Geologija. 32. 45-56.

48. Kazakauskas V., Gaigalas A. 2000. Kai kurie Lietuvos stambesniųjų prieledyninių ežerų sedimentacijos klausimai (On the problem of sedimentation in large periglacial lakes in Lithuania). Geologija. 32. 66-78.
49. Kazakauskas V., Gaigalas A. 2004. Varvometric estimation of the duration of Daniglacial glaciolacustrine sedimentation in Lithuania. Geologija. 48. 44-54.

50. Klimavičienè V. 1973. Rytų Žemaičių plynaukštès vèlyvojo ledynmečio limnoglacialinių baseinų geomorfologinė sąranga. Geografinis metraštis. 12. 57-70.

51. Köwing K. 1954. Das angebliche Oligozän bei Verden / Aller. Abhandlungen herausgegeben vom Naturwissenshaftlichen Vererein zu Bremen. 33. 491-495.

52. Ludwig A. 1963. Ein neuer Fährtenfund aus dem Bänderton. Geologie. 12. 493-496.

53. Merta T. 1980. Arthropod and mollusc traces in the varved clays of Central Poland. Acta Geologica Polonica. 30. 165-173.

54. Metz R. 1987. Sinusoidal trail formed by a recent biting midge (family Ceratopogonidae): trace fossil implications. Journal of Paleontology. 61. 312-314.

55. Metz R. 1998. Nematode trails from the Late Triassic of Pennsylvania. Ichnos. 5. 303-308.

56. Michealis P. 1972. Belorhaphe kochi (Ludwig 1969), eine Wurmspur im europäischen Karbon. Geologische Jahrbuch. 71. 299-330.

57. Mikaila V. 1957. Stambesniujų pietų ir vidurio Lietuvos TSR limnoglacialinių baseinų išplitimo, struktūros ir trukmès klausimu. Lietuvos TSR MA darbai. B ser. 4. 95-107.

58. Mikaila V. 1958. Lietuvos stambesniųjų limnoglacialinių baseinų nuosedos ir jų ryšiai su paskutiniuoju ledynu. Moksliniai pranešimai. Lietuvos TSR MA Geologijos ir geografijos institutas 7. 5-17.

59. Mikaila V. 1962(a). Limnoglacialinių baseinų ir juostuotų darinių formavimosi klausimu. Moksliniai pranešimai. Lietuvos TSR MA Geologijos ir geografijos institutas. 14. 1. 195-201.

60. Mikaila V. 1962(b). Lietuvos TSR stambesniųjų limnoglacialinių baseinų reikšmė ir perspektyvos statybinių medžiagų pramonei plèsti. Geografinis metraštis. 5. 143-158 p.

61. Mikaila V. 1966. Lietuvos TSR kvarterinių molių geologija ir litologija. Pietu Pabaltijo naudinguju iškasenų litologija ir geologija. Vilnius. 11-125.

62. Микалаускас А., Микутене Л. 1970. К вопросу существования лимногляциальных бассейнов на Средне-Литовской моренной равнине. История озер. Труды Всесоюзного симпозюма по основным проблемам пресноводных озер. 2. Vilnius. 206-216.

63. Moussa M. T. 1970. Nematode fossil trails from the Green River Formation (Eocene) in the Uinta Basin, Utah. Journal of Paleontology. 44. 304-307.

64. Murawski H. 1964. Tierfährten aus dem Pleistozän von Holstein. Eiszeitalter und Gegenwart. 15. 44-53.

65. Narbonne G. M., Aitken J. D. 1990. Ediacaran fossils from the Sekwi Brook area, Mackenzie Mountains, northwestern Canada. Palaeontology. 33. 945-980.

66. Pickerill R. K. 1987. Non-marine trace fossils from the Carboniferous Albert Formation, Southern New Brunswick, Eastern Canada. Proceedings of the 11th International Congress of Carboniferous Stratigraphy and Geology. Abstracts of Papers. Beijing. 82.

67. Pickerill R. K., Romano M., Melendez, B. 1984. Arenig trace fossils from Salamanca area, western Spain. Geological Journal. 19. 249-269. 
68. Ridge J. C., Larsen F. D. 1990. Re-evaluation of Antev's New England varve chronology and new radiocarbon dates of sediments from glacial Lake Hitchcock. Bulletin of the Geological Society of America. 102. 889-899.

69. Rindsberg A. K. 1994. Ichnology of the Upper Mississippian Hartselle Sandstone of Alabama, with notes on other Carboniferous Formations. Geological Survey of Alabama. Bulletin. 158. 1-107.

70. Rode H., Staar G. 1961. Die photographische Darstellung der Kriechspuren (Ichnogramme) von Nematoden und ihre Bedeutung. Nematologica. 6. 266-271.

71. Rolfe W. D. I. 1980. Early invertebrate terrestrial faunas. In: Panchen A. L. (ed.). The Terrestrial Environment and the Origin of Land Vertebrates. London and New York: Academic Press. 117-157.

72. Sandstedt R., Sullivan T., Schuster M. L. 1961. Nematode tracks in the study of movement of Meloidogyne incognita incognita. Nematologica. 6. 261-265.

73. Schwarzbach M. 1938. Tierfährten aus eiszeitlichen Bändertonen. Zeitschrift für Geschiebeforschung und Flachlandsgeologie. 14. 143-152.

74. Schwarzbach M. 1940. Das diluviale Klima während des Höchstandes einer Vereisung. Zeitschrift der Deutschen Geologischen Gesellschaft. 92. 565-582.

75. Skompski S. 1991. Trace fossils in the deposits of icedammed lakes. Kwartalnik Geologiczny. 35. 119-130.

76. Stanley D. C. A., Pickerill R. K. 1998. Systematic ichnology of the Late Ordovician Georgian Bay Formation of southern Ontario. Royal Ontario Museum. Life Sciences Contributions. 162. 1-56.

77. Šinkūnas P., Jurgaitis A. 1998. Glacigeninès sedimentacijos tyrimų litogenetiniai aspektai. Geologija. 23. 99-105.

78. Tarr W. A. 1935. Concretions in the Champlain Formation of the Connecticut River Valley. Bulletin of the Geological Society of America. 46. 1493-1534.

79. Toula F. 1908. Kriechspuren von Pisidium amnicum Müller. Beobachtungen auf einer Donauschlickbarre bei Kahlenbergerdorf-Wien. Verhandlungen der kaiserlicheköniglichen geologischen Bundesanstalt. 1908(11). 239-244.

80. Uchman A., Gaigalas A., Kazakauskas V. 2007. Trace fossils from Pleistocene lacustrine varve clays in some localities of Lithuania. Limneology: tales of an evolving Earth, 4th International Limneology Congress, ILIC 2007, Barcelona. Programme and abstract book. Planetearth, Earth Sciences for Society, Barcelona, p. 42.

81. Uchman A., Kazakauskas V., Gaigalas A. Trace fossils from Late Pleistocene varved lacustrine sediments in eastern Lithuania. Palaeogeography, Palaeoclimatology, Palaeoecology (in press).

82. Walker E. F. 1985. Arthropod ichnofauna of the Old Red sandstone at Dunure and Montrose, Scotland. Transaction of the Royal Society of Edinburgh. Earth Sciences. 76. 287-297.

83. Walter H. 1985. Zur Ichnologie des Pleistozäns von Liebegast. Freiberger Forschungshefte. C 400. 101-116.

84. Walter H. 1986. Arthropodenfärten in eiszitlichen Bändertonen bei Liebegast, Kreis Hoyerswerda. Natur und Landschaft im Bezirk Cottbus. NBLC. 8. 51-58.
85. Walter H., Hofmann U. 2001. Lebensspuren (Ichnia) aus dem Rotliegend der Döhlen-Senke (Sachsen). Freiberger Forschungshefte. C 492. 121-158.

86. Walter H., Suhr, P. 1998. Lebensspuren aus kalzeitlichen Bändersedimenten des Quartärs. Abhandlungen des Staatlichen Museums für Mineralogie und Geologie zu Dresen. 43/44. 311-328.

\section{Alfredas Uchmanas, Algirdas Gaigalas, Vaidotas Kazakauskas}

\section{ŠLIAUŽIOJANČIŲ GYVIŲ PĖDSAKAI (ICHNOFOSILIJOS) LIETUVOS VIRŠUTINIO PLEISTOCENO LIMNOGLACIALINĖSE SLUOKSNIUOTOSE NUOSĖDOSE}

\section{Santrauka}

Nuodugniai ichnologiniu metodu ištirtuose penkiuose limnoglacialinių nuosėdų pjūviuose Lietuvoje (Pašaminè-1, Balbieriškis-2, Balbieriškis-3, Krūna-1 ir Tauragè-1) daugiausia rasta Gordia, Helminthoidichnites ir Glaciichnium ichnogenčių šliaužiojančių gyvių pédsakų, šiek tiek randama Cochlichnus, Warvichnium ir "lanko" formos pèdsakų. Šios ichnofosilijos priklauso Mermia ichnofacijai, kuri būdinga ežerinėms aplinkoms. Jų buvimas limnoglacialinių nuosèdų sluoksnelių paviršiuose yra susijęs su vèlyvojo pleistoceno klimato atšilimo laikotarpiais, t. y. su tarpfazialais ir tarposciliacijomis. Pèdsakus palikusių gyvių suaktyvejiimas pastebimas vasarą, nes visos ichnofosilijos surastos ant žiemą suklostytų molingų sluoksnelių paviršių. Ichnofosilijų pasiskirstymas tirtuose pjūviuose yra gana nevienodas: Cochlichnus yra labai paplitusi Pašaminès-1 ir Pašaminès-2 pjūviuose, bet neaptikta Balbieriškio-1 pjūvyje. Warvichnium taip pat gana dažna Pašaminès pjūviuose ir retesne Balbieriškio-1 pjūvyje bei visiškai nerasta likusiuose tirtuose pjūviuose. Balbieriškio-1 ir Pašaminès-1 pjūviuose surasti 5 ichnogenčių, o Krūnos-1 pjūvyje - tik vienos ichnogenties pèdsakai. Šiuos skirtumus tikriausiai lèmè mažiausiai trys veiksniai: 1) ichnofosilijų asociacijų sudètis priklausè nuo ežero dugno zonos (metalimnijono ir hipolimnijono), 2) kiekvienas ežeras turejo tik jam būdingą faunos asociaciją ir 3) ichnofosilijos netolygiai yra pasiskirsčiusios horizontalia kryptimi ir todèl gali būti nesurastos siaurame vertikaliame pjūvyje. Šliaužiojančiu gyvių pédsakai dažniausiai aptikti tirtų pjūvių apatinėse ir rečiau vidurinèse dalyse esančiu varvinio sluoksniuotumo intervalų atskiruose sluoksneliuose ir sluoksnelių serijose, tuo tarpu kitose vietose net iki metro storio sluoksnelių serijose ichnofosilijų nerasta. Toks sluoksnelių su ichnofosilijomis ir be jų persisluoksniavimas galbūt atspindi klimato sąlygų kaitą ir mūsų atveju yra susijęs su Nemuno ledynmečio tarpfazialais ir tarposciliacijomis. Prieledyninių ežerų formavimuisi turẻjo ittakos ledyno dangos pasitraukimas iš Lietuvos ir klimato atšilimas apskritai, o šliaužiojančių gyvių pèdsakų buvimas limnoglacialinèse nuosèdose atspindi atšilimo laikotarpius Nemuno ledynmečio Baltijos stadijos Rytų Lietuvos-Pietų Lietuvos ir Pietų Lietuvos-Vidurio Lietuvos tarpfazių metu. Šiltesnio klimato tarpfazialai arba tarposciliacijos tirtuose nuosedų pjūviuose išsiskiria limninès sedimentacijos nuosedomis su Gordia, Helminthoidichnites, Glaciichnium ir retesesniais Cochlichnus bei Warvichnium ichnofosilijų radiniais sluoksneliu skilimo paviršiuose. Kaip rodo atlikti tyrimai, šliaužiojančių gyvių pèdsakų tyrimas Lietuvos limnoglacialinėse nuosėdose kartu su varvometriniu metodu gali būti labai efektyvus metodų kompleksas išskiriant šiltesnio klimato tarpfazialus ir osciliacijas vélyvojo pleistoceno ledyno degradacijos metu Lietuvos teritorijoje. 


\section{Альфред Ухман, Альгирдас Гайгалас, Вайдотас Казакаускас \\ СЛЕДЫ ИХНОФОССИЛИЙ В СЛОИСТЫХ \\ ЛИМНОГЛЯЦИАЛЬНЫХ ОТЛОЖЕНИЯХ ВЕРХНЕГО ПЛЕЙСТОЦЕНА ЛИТВЫ}

Резюме

В лимногляциальных отложениях Литвы, исследованных ихнологическим методом в пяти разрезах (Пашамине-1, Бальберишкис-2, Бальберишкис-3, Круна-1 и Таураге-1), выявлены следы жизнедеятельности Gordia, Helminthoidichnites и Glaciichnium, менее распространены Cochlichnus, Warvichnium и следы дугообразной формы. Эти ихнофоссилии относились к ихнофациям Mermia, характерным для озерных сред. Обнаруженные следы ихнофоссилий связаны с интервалами климатических потеплений в позднем плейстоцене, т.е.с межфазиальными или с межосцилляционными промежутками времени. Следы оставлены во время летней активизации ползающих организмов, так как они отмечены на поверхности глинистых слойков зимней седиментации. Распространение ихнофоссилий в изученных разрезах неоднородно: Cochlichnus выявлен в разрезах Пашамине-1 и Пашамине-2, а в разрезе Бальберишкис-1 не обнаружен. Warvichnium часто встречается в разрезах Пашамине, но редко - в Бальберишкис-1, а во всех остальных разрезах он не обнаружен. В разрезах Бальберишкис-1 и Пашамине-1 встречаются следы пяти родов ихнофоссилий, а в разрезе Круна-1 только одного. Эти различия, видимо, зависели от трех факторов: 1) условия донной зоны озера (металимнион и гиполимнион); 2) каждое озеро различалось ассоциациями характерной фауны; 3) ихнофоссилии неоднородно распределены по горизонтали и по этой причине они могут не проявляться в узком исследованном вертикальном разрезе отложений. Следы жизнедеятельности организмов наиболее часто проявлялись в нижней и реже в средней части разрезов в интервалах с ясно выраженной ленточной текстурой (в отдельных прослоях или в серии слойков), в других интервалах (достигающих до 1 метра) их не обнаружено. Такое переслаивание лимногляциальных отложений (интервалы с ихнофоссилиями и без них), возможно, отражает изменение климатических условий, в нашем случае связанных с межфазиалами и межосцилляциями поздненеманского ледниковья. Возникновение приледниковых озер было связано с отступанием покровного ледника с территории Литвы и с потеплением климата вообще. Следы организмов отражают интервалы потепления климата во время восточно-литовской-южнолитовской и южно-литовской-средне-литовской фаз балтийской стадии неманского оледенения. Межфазиалы и межосцилляции с более теплым климатом в исследованных разрезах проявляются слоистыми отложениями со следами жизнедеятельности Gordia, Helminthoidichnites, Glaciichnium и более редкими Cochlichnus и Warvichnium. Таким образом, следы ихнофоссилий в лимногляциальных отложениях наряду с варвометрическим методом в Литве могут эффективно использоваться для выявления более теплых межфазиалов и межосцилляций деградирующего ледникового покрова позднего плейстоцена. 